\title{
The Potential Role of Extracorporeal Cytokine Removal in Hemodynamic Stabilization in Hyperinflammatory Shock
}

\author{
Fatime Hawchar ${ }^{1, \dagger}$, Cristina Rao ${ }^{2, \dagger}$, Ali Akil ${ }^{3}$, Yatin Mehta ${ }^{4}$, Christopher Rugg ${ }^{5}{ }^{\circledR}$, Joerg Scheier ${ }^{2}$, \\ Harriet Adamson ${ }^{2}$, Efthymios Deliargyris ${ }^{6}$ and Zsolt Molnar $1,7,8,9, *$ (D)
}

1 Department of Anaesthesiology and Intensive Therapy, University of Szeged, 6 Semmelweis Str., H-6725 Szeged, Hungary; hawchar.fatime@med.u-szeged.hu

2 Cytosorbents Europe GmbH, Müggelseedamm 131, 12587 Berlin, Germany; cristina.rao@cytosorbents.com (C.R.); joerg.scheier@cytosorbents.com (J.S.); harriet.adamson@cytosorbents.com (H.A.)

3 Department of Thoracic Surgery and Lung Support, Klinikum Ibbenbueren, Grosse Strasse 41, 49477 Ibbenbueren, Germany; a.akil@klinikum-ibbenbueren.de

4 Institute of Critical Care and Anesthesiology, Medanta the Medicity, CH Baktawar Singh Rd, Gurugram 122001, Haryana, India; yatin.mehta@medanta.org

5 Department of Anesthesiology and Critical Care Medicine, Medical University of Innsbruck, Anichstrasse 35, 6020 Innsbruck, Austria; christopher.rugg@tirol-kliniken.at

6 Cytosorbents Corporation, 7 Deer Park Drive Suite K, Monmouth Junction, NJ 08852, USA; edeliargyris@cytosorbents.com

check for updates

Citation: Hawchar, F.; Rao, C.; Akil, A.; Mehta, Y.; Rugg, C.; Scheier, J.; Adamson, H.; Deliargyris, E; Molnar, Z. The Potential Role of Extracorporeal Cytokine Removal in Hemodynamic Stabilization in Hyperinflammatory Shock. Biomedicines 2021, 9, 768 . https://doi.org/10.3390/ biomedicines 9070768

\section{Academic Editors:}

Waldemar Kanczkowski and Koichi Yuki

Received: 10 April 2021

Accepted: 27 June 2021

Published: 1 July 2021

Publisher's Note: MDPI stays neutral with regard to jurisdictional claims in published maps and institutional affiliations.

Copyright: (C) 2021 by the authors. Licensee MDPI, Basel, Switzerland. This article is an open access article distributed under the terms and conditions of the Creative Commons Attribution (CC BY) license (https:// creativecommons.org/licenses/by/ $4.0 /)$.
7 Institute for Translational Medicine, School of Medicine, University of Pécs, Szigeti Str. 12, H-7624 Pécs, Hungary

8 Department of Anaesthesiology and Intensive Therapy and Pain Management, Poznan University for Medical Sciences, 61-701 Poznan, Poland

9 Department of Anaesthesiology and Intensive Therapy, Semmelweis University, 1085 Budapest, Hungary

* Correspondence: zsoltmolna@gmail.com

$+\quad$ F.H. and C.R. contributed equally to the manuscript.

\begin{abstract}
Hemodynamic instability due to dysregulated host response is a life-threatening condition requiring vasopressors and vital organ support. Hemoadsorption with Cytosorb has proven to be effective in reducing cytokines and possibly in attenuating the devastating effects of the cytokine storm originating from the immune over-response to the initial insult. We reviewed the PubMed database to assess evidence of the impact of Cytosorb on norepinephrine needs in the critically ill. We further analyzed those studies including data on control cohorts in a comparative pooled analysis, defining a treatment effect as the standardized mean differences in relative reductions in vasopressor dosage at $24 \mathrm{~h}$. The literature search returned 33 eligible studies. We found evidence of a significant reduction in norepinephrine requirement after treatment: median before, 0.55 (IQR: 0.39-0.90); after, $0.09(0.00-0.25) \mu \mathrm{g} / \mathrm{kg} / \mathrm{min}, p<0.001$. The pooled effect size at $24 \mathrm{~h}$ was large, though characterized by high heterogeneity. In light of the importance of a quick resolution of hemodynamic instability in the critically ill, further research is encouraged to enrich knowledge on the potentials of the therapy.
\end{abstract}

Keywords: shock; hemodynamic stabilization; hemoadsorption; cytosorb therapy; hypeinflammation; decatecholaminization

\section{Introduction}

Critical illness can occur due to several different etiologies, though commonly ending in similar trajectories. Regardless of the initiating insult, vital organ functions, not necessarily affected primarily, fall victim to a dysregulated host response [1]. Systemic hyperinflammation and the cytokine storm play a key role in this pathophysiology [2]. The cytokine storm originating from the immune over-response determines impairment of the vascular tone and systemic vasodilation, which manifests as hemodynamic instability. In its most serious form as vasoplegic circulatory shock, hemodynamic instability can be 
life-threatening; consequently, reversing shock as soon as possible is a lifesaving measure of utmost importance to avoid the devastating effects of hypoxemic organ damage [3]. CytoSorb(CytoSorbents, Monmouth Junction, NJ, USA) is a CE mark-approved extracorporeal therapy fort he adsorption and removal of small and middle-sized molecules in the blood (the adsorption spectrum is $5-60 \mathrm{kDa}$ ). The therapy has the potential to effectively remove cytokines originating from the cytokine storm [4,5], and thus can mitigate systemic hyperinflammation, contribute to early shock reversal, and last but not least, improve clinical outcomes. This systematic review will attempt to objectively assess the ability of CytoSorbtherapy (hereafter Cytosorb) to reduce the need of vasopressor support and to reverse vasoplegic shock, based on the available published literature.

\subsection{Physiology of Shock}

Shock is currently defined by the task force from the European Society of Intensive Care Medicine (ESICM) as a "life-threatening, generalized form of acute circulatory failure associated with inadequate oxygen utilization by the cells" [6]. Generally, this means an imbalance between oxygen delivery $\left(\mathrm{DO}_{2}\right)$ and oxygen consumption $\left(\mathrm{VO}_{2}\right) . \mathrm{DO}_{2}$ depends on cardiac output $(\mathrm{CO})$ and the arterial oxygen content $\left(\mathrm{CaO}_{2}\right)$, and $\mathrm{VO}_{2}$ depends on mixed venous oxygen content $\left(\mathrm{SvO}_{2}\right)$ :

$$
\begin{gathered}
\mathrm{DO}_{2}=\mathrm{CO} \times \mathrm{CaO}_{2} \\
\mathrm{CaO}_{2}=\mathrm{Hb} \times 1.34 \times \mathrm{SaO}_{2}+0.003 \times \mathrm{PaO}_{2} \\
\mathrm{DO}_{2}=\mathrm{CO} \times\left(\mathrm{Hb} \times 1.34 \times \mathrm{SaO}_{2}+0.003 \times \mathrm{PaO}_{2}\right) \\
\mathrm{VO}_{2}=\mathrm{CO} \times\left(\mathrm{CaO}_{2}-\mathrm{CvO}_{2}\right) \\
\mathrm{VO}_{2}=\mathrm{CO} \times\left[\left(\mathrm{Hb} \times 1.34 \times \mathrm{SaO}_{2}+0.003 \times \mathrm{PaO}_{2}\right)-\left(\mathrm{Hb} \times 1.34 \times \mathrm{SvO}_{2}+0.003 \times \mathrm{PvO}_{2}\right),\right.
\end{gathered}
$$

where $\mathrm{DO}_{2}$ is oxygen delivery; $\mathrm{CO}$ is cardiac output; $\mathrm{Hb}$ is hemoglobin; $\mathrm{SaO}_{2}$ is arterial oxygen saturation; $\mathrm{PaO}_{2}$ is partial pressure of oxygen in the arterial blood; $\mathrm{CaO}_{2}$ is arterial oxygen content; $\mathrm{VO}_{2}$ is oxygen consumption; $\mathrm{SvO}_{2}$ is mixed venous oxygen saturation; $\mathrm{CvO}_{2}$ is mixed venous oxygen content; $\mathrm{PvO}_{2}$ is mixed venous oxygen tension.

Adequate oxygen supply is paramount for preserving organ viability and is dependent on adequate tissue perfusion. The latter is commonly assessed by mean arterial pressure (MAP), which is mainly determined by vascular tone (systemic vascular resistance-SVR). The relationship between SVR, MAP, central venous pressure (CVP) and CO is described below, based on Ohm's law:

$$
\mathrm{SVR}=\frac{\mathrm{MAP}-\mathrm{CVP}}{\mathrm{CO}}
$$

With the help of these formulae, the mechanisms of the various shock types can be easily understood [7]. Loss of vascular tone (i.e., sepsis, hyperinflammation) results in low SVR, low MAP and preload deficit (i.e., vasoplegic shock). The different underlying mechanisms of hemodynamic instability also correspond to potential therapeutic options to be targeted, including fluids, inotropes, oxygen supplementation, and vasopressors to increase vascular tone, hence tissue perfusion. The differential diagnosis of hemodynamic instability or shock requires a skilled assessment of the complete clinical picture, which ranges from a simple measurement of vital signs such as heart rate and blood pressure, to complex, advanced hemodynamic monitoring [8]. Only after comprehensive assessment can the clinician determine the underlying pathophysiologic mechanisms and decide upon the best course of action and the right combination of interventions for each individual patient. The connection of inflammatory response-vasoplegia-tissue hypoperfusion-cytokine removal is depicted in Figure 1. 


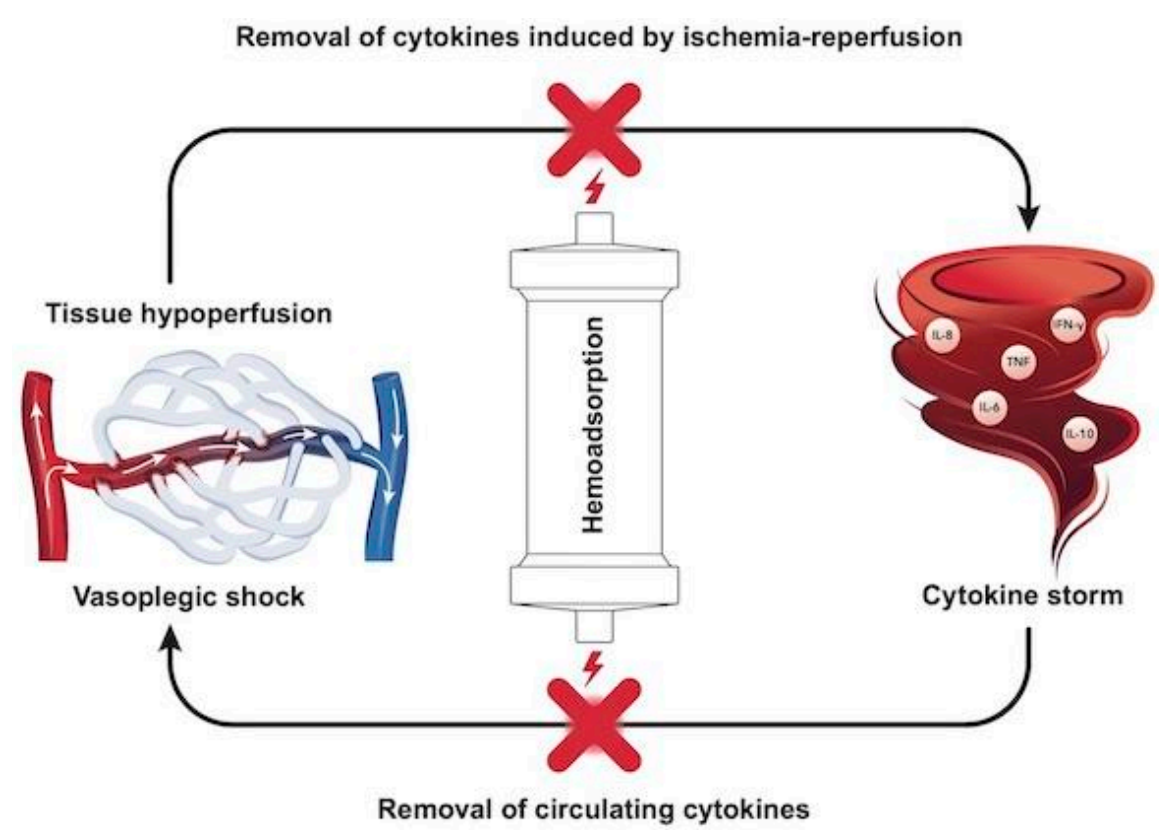

Figure 1. The vicious circle of hyperinflammation. Circulating cytokines can induce vasodilatation leading to arteriovenous shunting in the microcirculation and eventually vasoplegic shock. Hypoperfused tissues may further amplify the effects of cytokine storm byconcomittantly triggering an immune response, potentially leading to ischemia-reperfusion injury. Hemoadsorption can potentially attenuate this vicious circle and protect the tissues from this onslaught by removing circulating cytokines and those released after tissue injury.

Different types of shock require different management strategies. However, hemodynamic stabilization always represents a main goal due to its role in reestablishing adequate aerobic metabolism in the cells and tissues, and in regaining control over the oxygen debt. Oxygen debt also accumulates during the resuscitation period, suggesting that shorter resuscitation times translate into lesser oxygen debts. Experimental studies suggest that both the severity and duration of hemodynamic instability are associated with poor outcomes [9].

\subsection{Hyperinflammation and Vasoplegic Shock}

Vasoplegic shock in the setting of hyperinflammation is a particularly challenging scenario. In the past, the clinical and biochemical characteristics of vasoplegic shock were often defined within the domain of "septic shock". However, similar features are also observed in non-infective inflammatory states, such as in acute necrotizing pancreatitis, after major trauma, major surgery, and in other conditions without an obvious infectious component. In order to better capture the underlying pathophysiology, an updated definition was derived via expert consensus [1,10]. The main message of the updated definition is that the pathophysiological process is fundamentally the same regardless of the provoking injury/insult, and is mainly determined by the host response. This was in large part supported by the very important discovery that both pathogen- and damage-associated molecular patterns (PAMPs and DAMPs) can trigger a septic shock-like clinical picture [9]. Interestingly, very similar observations were made many years before by Sir William Osler in the context of bacterial infections [11], and Hans Janos Selye in the context of stress [12]. Based on our current understanding, the term "hyperinflammatory shock" is preferred over "septic shock", since it describes the pathophysiology more accurately and is applicable to both infectious and non-infectious etiologies.

The term "refractory shock" is commonly used to describe the most severe cases of hyperinflammatory shock. Although there is no clear consensus as to the exact definition for refractory shock, it is generally intended as shock persisting for more than $6 \mathrm{~h}$ despite initiation of full standard therapy, and is indicated by the following: 
- Elevated lactate levels (>2.9 mmol/L) [13];

- High norepinephrine (NE) requirements (>0.3 $\mu \mathrm{g} / \mathrm{kg} / \mathrm{min})$ [13].

\subsection{Shock and Shock Reversal}

Up to one-third of patients admitted to the intensive care unit (ICU) are in circulatory shock [14]. Septic shock is by far the most frequent type of shock (62\%) and carries a very high mortality ranging from 40 to $80 \%$ [15]. As noted already, the expert community now recommends the terms "hyperinflammatory" or "vasoplegic" shock over "septic shock" to better reflect the underlying pathophysiology of a "dysregulated host response" [1,5]. Several studies have demonstrated that both the severity and duration of hemodynamic instability (i.e., hypotension, low CO) are associated with poor outcomes [16,17]. Accordingly, current Surviving Sepsis Guidelines recommend early and aggressive resuscitation within the first hours of the onset of sepsis and septic shock [18]. Fluid resuscitation is usually the first step in the resuscitation algorithm. However, especially in vasoplegic shock, which is characterized by low SVR and consequently low diastolic blood pressure, a fluid challenge alone is often insufficient to improve tissue perfusion $[19,20]$. Starting vasopressors to increase the vascular tone and SVR together with fluid resuscitation in severe cases has a strong pathophysiological rationale. Clinical studies have shown that delaying the introduction of these therapeutic measures is associated with increased risk of death $[21,22]$.

Vasopressors exert their effect by either mimicking the effect of the sympathetic nervous system (sympathomimetic amines) or by raising extracellular ionized calcium concentrations (calcium chloride). Sympathomimetic amines can be divided into either catecholamines or non-catecholamines. Commonly used catecholamines with a prominent agonist activity include epinephrine (also known as adrenaline), norepinephrine (noradrenaline) and dopamine. Norepinephrine is recommended as first line treatment of septic shock by the Surviving Sepsis campaign, but the combined use of vasopressors including both vasopressin and norepinephrine is also suggested to limit adrenoceptor desensitization due to sympathetic hyperactivation $[23,24]$.

In patients with severe hyperinflammatory shock, neither vasopressors nor fluid resuscitation are effective in quickly reversing shock. Given the pathophysiological background, cytokine removal through hemoadsorption might be beneficial for patients showing resistance to resuscitation, i.e., not stabilized after $6 \mathrm{~h}$ of resuscitation and organ support. Cytokine removal can attenuate hyperinflammation and hence vasoplegia, leading to quicker hemodynamic stabilization and shock reversal. The most frequently used criteria to define shock reversal include normalization of serum lactate $(<2.2 \mathrm{mmol} / \mathrm{L})$ coupled with a significant $(\geq 90 \%)$ reduction in norepinephrine dose requirements $[13,25]$.

\section{Objectives}

This review is aimed at assessing the effect of hemoadsorption with Cytosorb on the need for vasopressor support. We achieved this by analyzing norepinephrine dose requirements before and after treatment with Cytosorb in patients with vasoplegic shock of various etiologies.

\section{Materials and Methods}

A literature search was conducted in PubMed (https:/ / pubmed.ncbi.nlm.nih.gov/, accessed on 10 March 2021), with the last update on 10 March 2021. The key search word "Cytosorb" was used for the search. We did not apply any restrictions in terms of study design. We selected articles reporting on requirements of norepinephrine to analyze whether a reduction in vasopressor support could be observed. We included only studies recording and reporting norepinephrine doses in the microgram per kilogram per minute $(\mu \mathrm{g} / \mathrm{kg} / \mathrm{min})$ measurement scale, and where the vasopressor dose was measured before and after treatment with Cytosorb. We summarized data from studies to assess the variation in vasopressor needs before and after treatment with Cytosorb, without considering 
the heterogeneity existing among different sources. In addition to the descriptive study, a pooled comparative analysis was conducted for studies including data on control cohorts. The effect size was expressed as the standardized mean difference of the relative reduction in the need for vasopressor support from baseline to $24 \mathrm{~h}$.The analysis of data was conducted using Microsoft Excel version 16 (Microsoft Corporation. 2019. Redmond, WA, USA) and STATA statistical software, release 16 (StataCorp LLC. 2019. College Station, TX, USA).

\section{Results}

Out of the 163 clinical articles available in PubMed, 58 were identified that mentioned "catecholamines and/or vasopressors". In total, 25 papers were excluded; 12 because of non-comparability of the measurement scales [25-36]; 4 because the type and dose of vasopressors were not specified [37-40]; 1 that reported combined norepinephrine and epinephrine doses [41]; 1 that only reported on patients that had survived [42]; and 7 where there were no measurements pre- and post-adsorber use in the same patient [43-49]. The remaining 33 articles were summarized without considering different study designs or duration of treatment. Overall, data on 353 patients treated with Cytosorb were collected.

Table A1 in Appendix A depicts details from articles included in our review [13,50-81]. From these papers, four were selected for a pooled comparative analysis due to their inclusion of both Cytosorb and a control cohort [64,75,77,79].

The highest and the lowest administered doses of norepinephrine for each day were reported at 24, 48, 72 or $96 \mathrm{~h}$ after the start of Cytosorb treatment, depending on the specific study. We assumed as the pre-Cytosorb value the dose administered before the start of the therapy or the highest dose recorded during the first $24 \mathrm{~h}$ before the start of hemoadsorption, depending on data availability, and the post-Cytosorb value as the lowest dose of norepinephrine administered and recorded during the last reported day. We assumed the last available norepinephrine dose measurement to be at the end of Cytosorb therapy for all patients in all studies analyzed. However, we are aware of at least one study [13] wherein the norepinephrine dose was measured and recorded only during the first day, while the therapy was used for an additional two days. We still used the lowest available dose to determine norepinephrine requirements after hemoadsorption treatment.

The descriptive analysis comprised 21 case reports, 11 case series and one randomized trial, and did not consider differences in the number of adsorbers used or the duration of treatment sessions. The results of the analysis are summarized in Figure 2.

In 14 articles, including three case series, norepinephrine was weaned off after treatment with Cytosorb. Norepinephrine dosage was higher than $0.5 \mu \mathrm{g} / \mathrm{kg} / \mathrm{min}$ at the end of the treatment with Cytosorb in one case report [74], and in two case series [12,78]. The median dosage of norepinephrine required decreased by a full order of magnitude at the end of Cytosorb therapy. Overall, the available evidence shows that the norepinephrine dose requirements were markedly lower after Cytosorb treatment. 


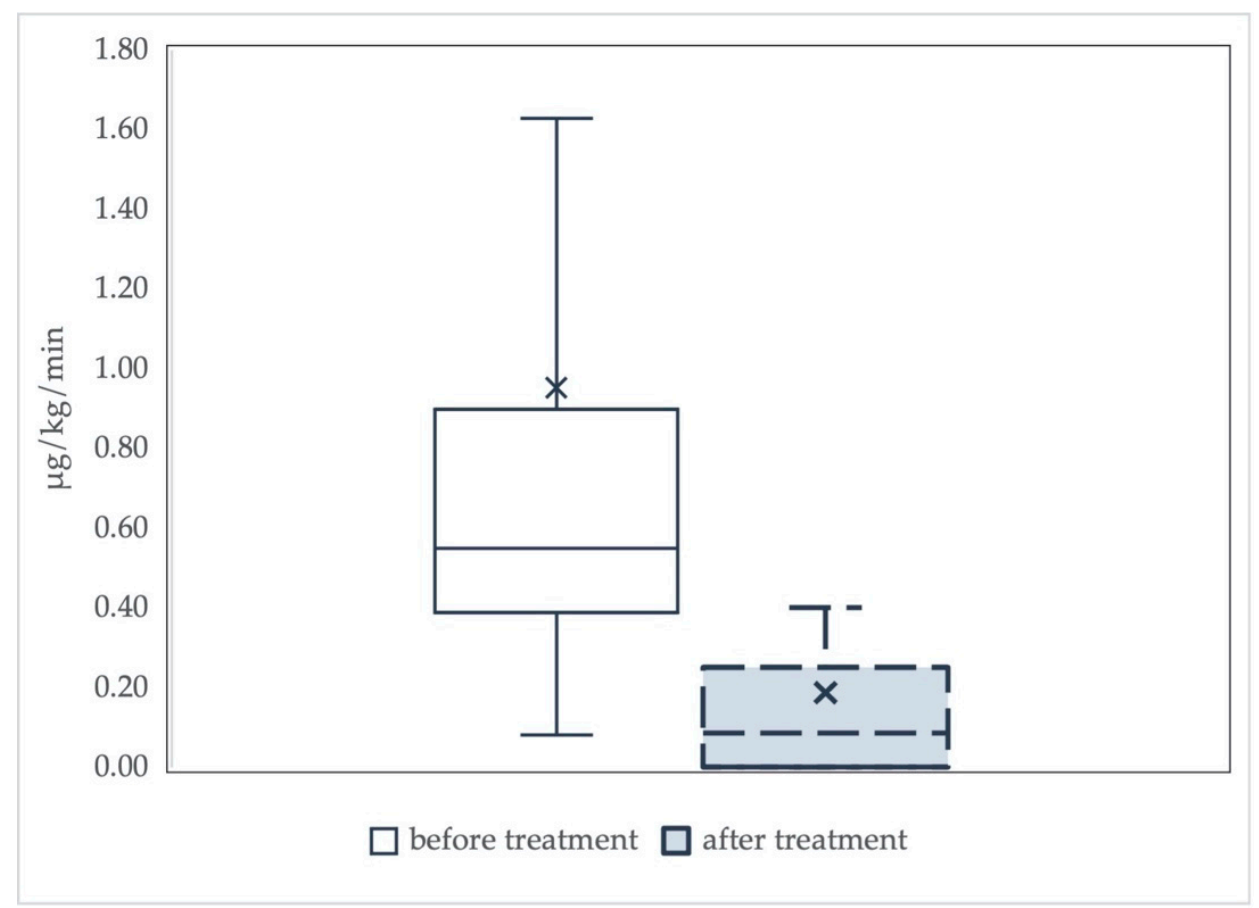

Figure 2. Norepinephrine requirements before and after treatment with Cytosorb. Data are summarized as boxplots. The " $x$ " in the box represents the mean value. There is a significant decline in median norepinephrine requirements before and after hemoadsorption with Cytosorb (from 0.55 $(0.39-0.9) \mu \mathrm{g} / \mathrm{kg} / \mathrm{min}$ to $0.09(0.0-0.25) \mu \mathrm{g} / \mathrm{kg} / \mathrm{min}, p<0.001)$.

\subsection{Analysis of Studies with Control Cohorts}

Four of the articles reported norepinephrine requirements in patients treated with Cytosorb as well as in a control cohort not treated with Cytosorb (Table 1).

Table 1. Studies with Cytosorb and control cohorts.

\begin{tabular}{clcccc}
\hline Study & Design & Indication & Cytosorb, $\boldsymbol{n}$ & Control, $\boldsymbol{n}$ & Total \\
\hline Mehta et al. [77] & Observational & Aortic surgery & 8 & 8 & 16 \\
Hawchar et al. [64] & Randomized & Septic shock & 10 & 10 & 20 \\
Akil et al. [75] & Observational & Septic shock & 13 & 7 & 20 \\
Rugg et al. [79] & Observational & Septic shock & 42 & 42 & 84 \\
Total & - & - & 73 & 67 & 140 \\
\hline
\end{tabular}

Summary results for the selected studies are depicted in Figure 3.

Mehta et al. [77] compared outcomes between patients undergoing aortic surgery with Cytosorb installed in the cardiopulmonary bypass circuit with patients undergoing conventional surgery without Cytosorb adsorber. At baseline, after the induction of anesthesia, there was no difference in the median dosage of norepinephrine in the Cytosorb or control groups, and vasopressor requirements remained similar at $2 \mathrm{~h}$ after discontinuation of $\mathrm{CPB}$ (Figure 3a). However, by $24 \mathrm{~h}$ after surgery, the median need for vasopressor dose was significantly lower in the Cytosorb group compared to controls. After $48 \mathrm{~h}$, all patients were either weaned off or only had minimal vasopressor requirements. 


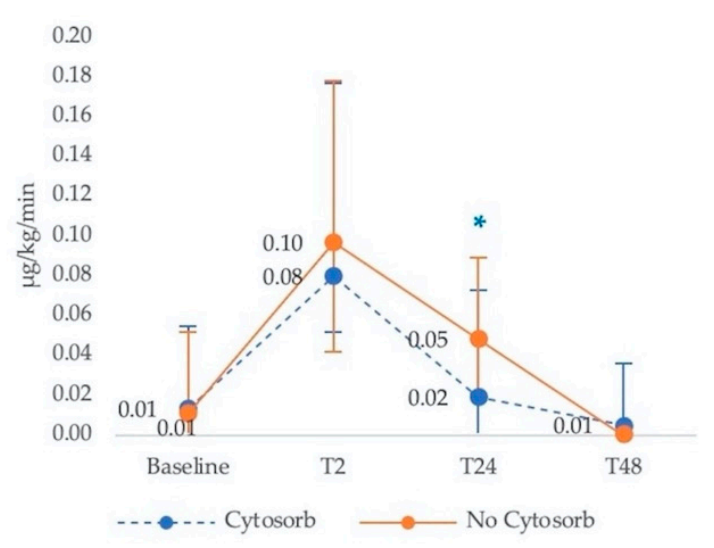

(a)

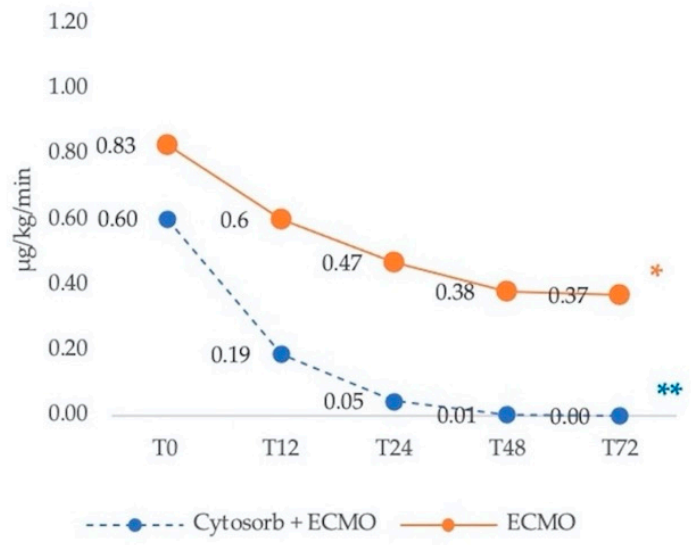

(c)

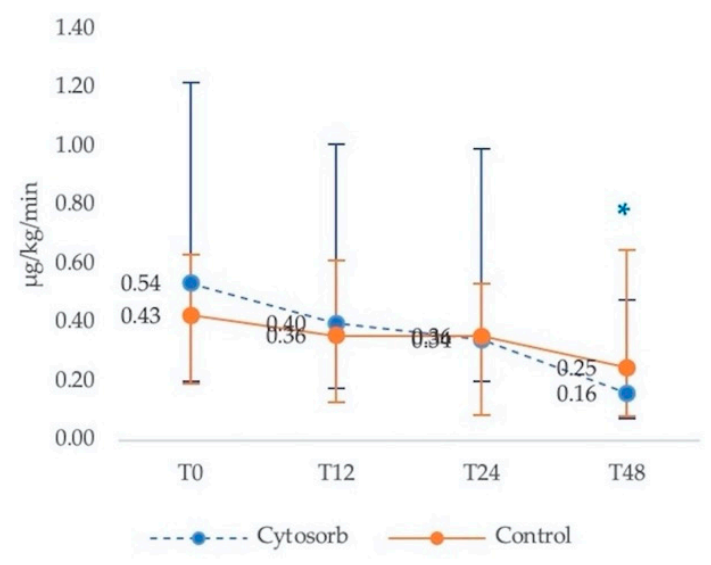

(b)

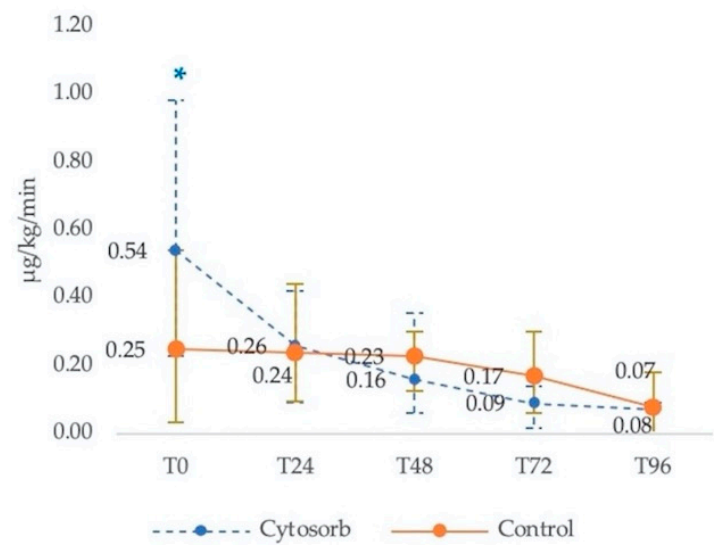

(d)

Figure 3. Median vasopressor therapy requirements in Cytosorb and control cohorts. (a) Median vasopressor therapy requirements in aortic surgery patients. Based on Mehta et al. [77]. ${ }^{*} p<0.05$ for NE dose of Cytosorb vs. no Cytosorb at T24. (b) Median vasopressor therapy requirements in septic patients. Based on Hawchar et al. [64]. $\mathrm{T}_{0}$ is measured right after inclusion (control) or start of hemoadsorption. $\mathrm{T}_{12}, \mathrm{~T}_{24}$ and $\mathrm{T}_{48}$ were measured 12,24 and $48 \mathrm{~h}$ later. ${ }^{*} p<0.05$ vs. $\mathrm{T}_{0}$ in the Cytosorb group. (c) Mean vasopressor therapy requirements in patient with pneumonia-derived sepsis. Based on Akil et al. [29]. Timepoints represent hours after the initial dose administered at the entrance into the ICU. ${ }^{*} p=0.05$ at $\mathrm{T}_{48}$ and $\mathrm{T}_{72}$ in the ECMO group. ${ }^{* *} p<0.005$ at $\mathrm{T}_{12}, \mathrm{~T}_{24}, \mathrm{~T}_{48}$ and $\mathrm{T}_{72}$ in the Cytosorb group. (d) Median vasopressor therapy requirements in septic shock patients requiring CRRT. Based on Rugg et al. [79]. Baseline is defined as the day of Cytosorb mounting in the treatment group. Data are presented as median and interquartile ranges. ${ }^{*} p=0.014$ as compared to baseline. For explanation see text.

The remaining three articles included septic shock patients, and in all of these the use of Cytosorb was associated with a quicker reduction in norepinephrine needs [64,75].

In Hawchar et al. [64], 20 patients with early onset sepsis were randomly assigned to receive either Cytosorb $(n=10)$ or standard care $(n=10)$. All patients were mechanically ventilated and on hemodynamic monitoring-guided norepinephrine. Although norepinephrine requirements declined in both groups over time, the decline after $48 \mathrm{~h}$ was only significant in the Cytosorb group. Specifically, in the Cytosorb group, norepinephrine doses declined at a steady rate and significantly over $48 \mathrm{~h}$ (Figure $3 \mathrm{~b}$ ). In the control group, lesser and slower declines in norepinephrine requirements over time were observed, with the overall trend not being significant. The mean change $(\Delta)$ in norepineprine requirements between baseline and $48 \mathrm{~h}$ was also significantly greater in the Cytosorb group $(0.67 \mu \mathrm{g} / \mathrm{kg} / \mathrm{min}$ vs. $0.10 \mu \mathrm{g} / \mathrm{kg} / \mathrm{min} ; p=0.047)$.

In another study investigating the role of Cytosorb in septic patients, Akil and colleagues [75] prospectively compared 13 patients who developed acute respiratory distress 
syndrome (ARDS) from pneumonia-derived sepsis and were treated with veno-venous extracorporeal membrane oxygenation (ECMO) plus Cytosorb to a historical cohort of 7 pulmonary sepsis patients treated with ECMO alone. At the time of admission to the ICU, norepinephrine dose was slightly lower in the Cytosorb group compared to controls, but both patient groups required high vasopressor support (Figure 3c).

Although reductions in vasopressor requirements were observed in both groups, the decline in the hemoadsorption group was more rapid and more pronounced. Specifically, median norepinephrine dose was significantly reduced after 12, 24 and $48 \mathrm{~h}$ of treatment compared to the initial dose required at the time of admission in the ICU. After $72 \mathrm{~h}$, none of the Cytosorb patients required norepinephrine, while in the control group, high norepinephrine doses were still needed after $12,24,48$ and $72 \mathrm{~h}$ after admission to the ICU (Figure 3c).

Finally, in a retrospective study of Cytosorb in septic shock patients, Rugg and colleagues [79] compared the catecholamine requirements of 42 septic shock patients treated with Cytosorb and continuous renal replacement therapy (CRRT) to a genetic-matched control of 42 patients receiving CRRT alone. Baseline catecholamine requirements were significantly lower in the control group compared with the Cytosorb group, suggesting that the latter patients were sicker. However, within $24 \mathrm{~h}$ of Cytosorb initiation, norepinephrine doses were halved, while no change was seen in the control group. By $96 \mathrm{~h}$, the vasopressor requirements were similar in both groups, but the overall reduction in patients not receiving Cytosorb therapy was modest and very slow (Figure 3d).

\subsection{Pooled Analysis}

We pooled together the results from the four studies with control cohorts to estimate the effect size of the benefit associated with the use of Cytosorb treatment, expressed in terms of reduced need of vasopressor support at $24 \mathrm{~h}$.

The meta-analysis was run on STATA 16 [82] using the meta command. The effect size was estimated as the standardized mean difference of the relative reduction in the need for vasopressor support from baseline to $24 \mathrm{~h}$. We used Hedge's g statistical method, which is preferred for estimates on small samples. The effect size according to Hedge's $g$ is interpreted following a rule of thumb:

- $\quad$ Small effect $=0.2$;

- $\quad$ Medium effect $=0.5$;

- $\quad$ Large effect $=0.8$.

Figure 4 below summarizes the results of the pooled analysis.

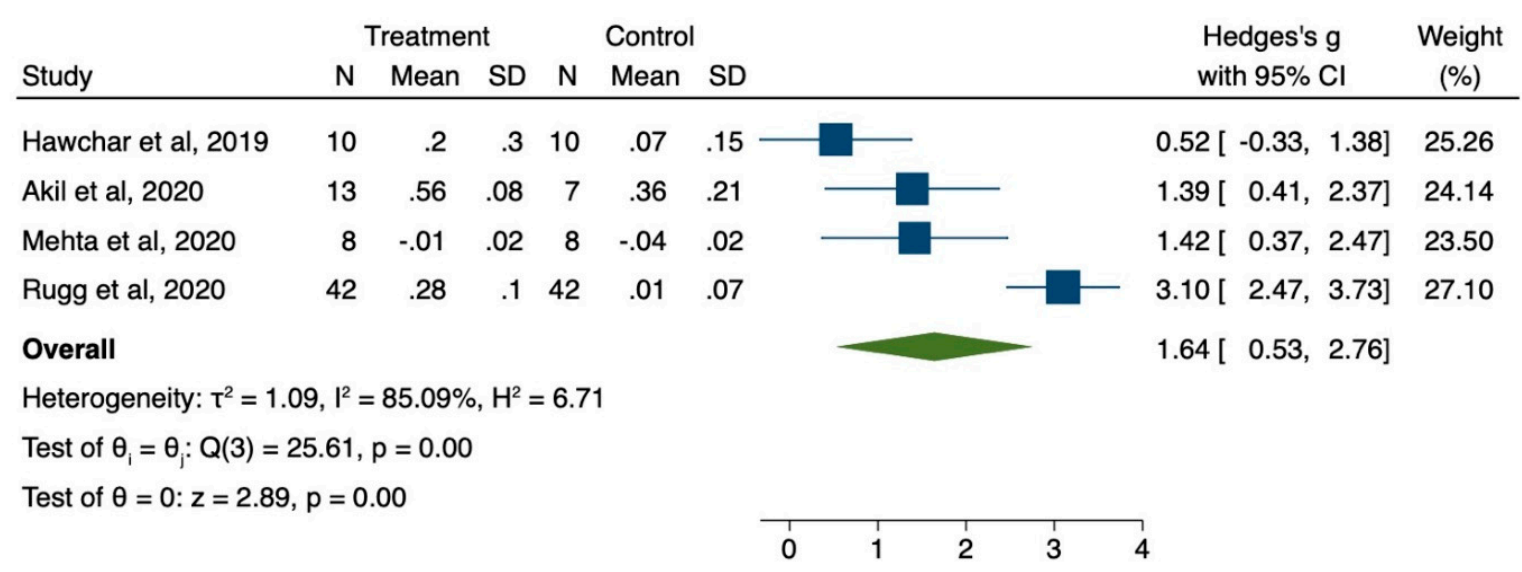

Random-effects REML model

Figure 4. Forest plot for efficacy of CS therapy to reduce NE requirements at $24 \mathrm{~h}$. 
The pooled effect size at $24 \mathrm{~h}$ was large and statistically significant. Despite the consistency in the direction of the treatment effect, the $\mathrm{I}^{2}$ statistic suggests a high degree of heterogeneity in the size of the treatment effect between the studies.

\section{Discussion}

Despite advancements in critical care medicine, critical illness and hyperinflammatory shock are still characterized by high mortality all over the world, and create a huge demand for advancements in critical care. The available therapeutic strategies aim at supporting the impaired organ function and at re-establishing hemodynamic stability.

Fluid resuscitation and vasopressor therapies represent important first-line options in these patients. However, both excessive fluid administration and high doses or prolonged usage of vasopressors can lead to potential patient harm [19]. First, fluid overload can trigger respiratory and cardiac strain, both manifesting in worsening hypoxemia and myocardial ischemia. For this reason, fluid "de-resuscitation" should be aggressively pursued after hemodynamic stabilization is established. Second, vasopressors may cause vasoconstriction in the arterioles, and thus decrease microvascular perfusion, an effect demonstrated in both healthy subjects [83] and critically ill patients [84,85]. The potentially serious adverse effects of high-dose vasopressor administration include digital ischemia, tachyarrhythmias, facilitation of bacterial growth, and compromised host resistance to bacteria [86] (Table 2).

Table 2. Studies with CytoSorb and control cohorts.

\begin{tabular}{|c|c|c|}
\hline Vasopressor & Dose & Potential Side Effects \\
\hline Norepinephrine (noradrenaline) & $0.05-0.1 \mathrm{mcg} / \mathrm{kg} / \mathrm{min}$ & $\begin{array}{l}\text { Acute glaucoma; anxiety, arrhythmias; asthenia; cardiomyopathy; } \\
\text { confusion; dyspnea; extravasation necrosis; gangrene; headache; } \\
\text { heart failure; hypovolemia; hypoxia; injection site necrosis; } \\
\text { insomnia; ischemia; increased myocardial contractility; nausea; } \\
\text { palpitations; peripheral ischemia; psychotic disorder; respiratory } \\
\text { failure; tremor; urinary retention; vomiting }\end{array}$ \\
\hline Dopamine & $\mathrm{Up}$ to $20 \mathrm{mcg} / \mathrm{kg} / \mathrm{min}$ & $\begin{array}{c}\text { Angina pectoris; anxiety; arrhythmias; azotemia; cardiac } \\
\text { conduction disorder; dyspnea; gangrene; headache; hypertension; } \\
\text { mydriasis; nausea; palpitations; piloerection; polyuria; } \\
\text { tremor; vasoconstriction; vomiting }\end{array}$ \\
\hline Epinephrine (adrenaline) & $0.01-0.1 \mathrm{mcg} / \mathrm{kg} / \mathrm{min}$ & $\begin{array}{l}\text { Angina pectoris; angle closure glaucoma; anxiety; appetite } \\
\text { decreased; arrhythmias; asthenia; CNS; hemorrhage; confusion; } \\
\text { dizziness; dry mouth; dyspnea; headache; hepatic necrosis; } \\
\text { hyperglycemia; hyperhidrosis; hypersalivation; hypertension } \\
\text { (increased risk of cerebral hemorrhage); hypokalemia; injection site } \\
\text { necrosis; insomnia;intestinal necrosis; metabolic acidosis; } \\
\text { mydriasis;myocardial infarction; nausea; pallor; palpitations; } \\
\text { peripheral coldness; psychosis; pulmonary edema (on excessive } \\
\text { dosage or extreme sensitivity); renal necrosis; soft tissue necrosis; } \\
\text { tremor; urinary disorders; vomiting }\end{array}$ \\
\hline Vasopressin & $0.01-0.07$ units $/ \mathrm{min}$ & $\begin{array}{c}\text { Abdominal pain; angina pectoris; bronchospasm; cardiac arrest; } \\
\text { chest pain; diarrhea; pain; flatulence; fluid imbalance; gangrene; } \\
\text { headache; hyperhidrosis; hypertension; musculoskeletal chest pain; } \\
\text { nausea; pallor; peripheral ischemia; tremor; urticaria; } \\
\text { vomiting; vertigo }\end{array}$ \\
\hline Dobutamine & $2.5-10 \mathrm{mcg} / \mathrm{kg} / \mathrm{min}$ & $\begin{array}{l}\text { Arrhythmias; bronchospasm; chest pain; dyspnea; eosinophilia; } \\
\text { fever; headache; localized inflammation; ischemic heart disease; } \\
\text { nausea; palpitations; platelet aggregation inhibition (on prolonged } \\
\text { administration); skin reactions; urinary urgency; vasoconstriction }\end{array}$ \\
\hline
\end{tabular}

Please note, the depicted doses refer to the most frequently reported values and do not represent recommendations.

Importantly, several retrospective studies have concluded that the prolonged use of high-dose norepinephrine is associated with poor outcomes, and is also a strong predictor of death $[87,88]$. Although one could argue that high-dose vasopressors are simply a surrogate marker of disease severity in these patients, these results suggest that reducing the need for vasopressor support in terms of both time and dosage could be beneficial for patients. 
These findings emphasize the importance of shock reversal with concomitant "decatecholamisation", to be performed as quickly as possible [89-92].

Cytosorb is a European CE-marked therapy able to adsorb and thus remove cytokines from the blood, attenuating the devastating effects of the cytokine storm. In this review, we have found a significant decline in vasopressor support requirements after treatment with hemoadsorption in the critically ill. In addition, based on a pooled analysis of studies including data on control cohorts, we have found evidence of a large treatment effect of the therapy at $24 \mathrm{~h}$ from baseline. This finding was characterized by large heterogeneity, indicating variability among studies.

The paper has several limitations. For example, we described the change in norepinephrine dose requirements in the Cytosorb population by including all types of published articles. In fact, data were generated from extremely heterogeneous sources with no standardization in regard to patients (besides observational studies, 25 single case reports), pathophysiology, clinical circumstances and time frame of observation. Furthermore, we could not take into consideration the number of adsorbers used during the observational period considered, nor the duration of use of each hemoadsorption cartridge, or whether the therapy continued after the last available vasopressor dose measurement. Another limitation is that we only evaluated one hemoadsorption device. Although there are other hemoadsorbers on the market (Jafron, Jafron Biomedical Co., Guangdong, China; Biosky, Biosun Medical Technology Co., Foshan, China), published data are extremely scarce in general, and none are available in the current context of hemodynamic stabilization, as was nicely summarized in a recently published review by Krenn and Stelzer [93]. Finally, we cannot make any comments on either shock reversal—as data on metabolic changes are missing - or on other beneficial effects on outcome, including survival. These issues have to be raised and answered in large prospective randomized studies.

Nevertheless, the results of this analysis encourage more research to be done in order to assess the potential use of the therapy in accelerating shock reversal and improving outcomes in the critically ill. Finally, the topics discussed here also provide food for thought on the need to better investigate the benefits derived from early control of the escalating cytokine storm in pre-hyperinflammatory states.

\section{Conclusions}

Intensive care medicine is one of the most dynamic fields in medicine, and is constantly evolving in terms of both disease state understanding and treatment advancements. The new definition of sepsis emphasizes the importance of "dysregulated immune response", and other new terms increasingly used in this clinical setting include: hyperinflammation, cytokine storm, vasoplegic shock, refractory shock and shock reversal. These concepts more accurately reflect the improved understanding of the underlying pathophysiologic mechanisms, and as such could also help define priorities and clinical endpoints in the design of future clinical trials. Such an approach may also address the concerns of many experts that mortality may no longer be the only appropriate primary endpoint for clinical trials in this setting [94,95]. This is supported by recent trials in sepsis, applying composite clinical outcomes such as "vasopressor and mechanical ventilation-free days" as primary endpoints instead of mortality [96,97]. The current paper has summarized the available data, which indicate the important contribution of early hemoadsorption in achieving rapid hemodynamic stabilization in patients with refractory vasoplegic shock.

Author Contributions: Conceptualizatoin and methodology Z.M., E.D., J.S., C.R. (Cristina Rao), F.H.; literature search and data extraction H.A; formal analysis C.R. (Cristina Rao); writing-original draft preparation F.H., C.R. (Cristina Rao), H.A., Z.M.; writing-review and editing J.S., E.D., A.A., Y.M., C.R. (Christopher Rugg). All authors have read and agreed to the published version of the manuscript.

Funding: This research received no external funding.

Institutional Review Board Statement: Not applicable. 
Informed Consent Statement: Not applicable.

Data Availability Statement: The data presented in this study are available on request from the corresponding author.

Conflicts of Interest: Z.M., J.S., C.R. (Cristina Rao), H.A. are employed by Cytosorbents Europe $\mathrm{GmbH}$. E.D. is employed by Cytosorbents Corporation. The other authors have no conflict of interest.

\section{Appendix A}

Table A1 reports details of studies included in this review.

Table A1. Details of included studies.

\begin{tabular}{|c|c|c|c|c|c|c|}
\hline Reference & Type of Patients & Num of pts & $\begin{array}{l}\text { Avg. Num } \\
\text { of Adsorbers }\end{array}$ & $\begin{array}{l}\text { Time Frame } \\
\text { for Use }\end{array}$ & End Points & Results \\
\hline Mitzner et al. [50] & Septic shock & 1 & 1 & $24 \mathrm{~h}$ & None stated & $\begin{array}{l}86.67 \% \text { reduction in } \\
\text { norepinephrine use } \\
\text { in } 24 \mathrm{~h}\end{array}$ \\
\hline Hetz et al. [51] & Septic Shock & 1 & 3 & $24 \mathrm{~h}$ each & None stated & $\begin{array}{l}83.05 \% \text { reduction in } \\
\text { norepinephrine use } \\
\text { in first } 24 \mathrm{~h}\end{array}$ \\
\hline Frimmel et al. [52] & Viral shock, ALF & 1 & 1 & $24 \mathrm{~h}$ & None stated & $\begin{array}{l}58.33 \% \text { reduction in } \\
\text { norepinephrine use } \\
\text { in } 24 \mathrm{~h}\end{array}$ \\
\hline Hinz et al. [53] & Septic shock, ALF & 1 & 3 & $\begin{array}{c}\text { 1. } 24 \mathrm{~h}, 2.2 .6 \mathrm{~h}, \\
\text { 3. } 5 \text { days later } \\
24 \mathrm{~h}\end{array}$ & None stated & $\begin{array}{l}76.25 \% \text { reduction } \\
\text { over } 3 \text { days }\end{array}$ \\
\hline Traegar et al. [54] & $\begin{array}{l}\text { Septic shock, } \\
\text { ARDS }\end{array}$ & 1 & 3 & $\begin{array}{c}\text { 1. } 20 \mathrm{~h}, 2.35 \mathrm{~h}, \\
\text { 3. } 29 \mathrm{~h}\end{array}$ & None stated & $\begin{array}{c}50 \% \text { increase in } \\
\text { norepinephrine use } \\
\text { after 1st treatment, } \\
66.6 \% \text { decrease on } \\
\text { 2nd treatment, } 100 \% \\
\text { decrease day } 3 .\end{array}$ \\
\hline Van der Linde et al. [55] & $\begin{array}{l}\text { Septic shock, } \\
\text { ARDS }\end{array}$ & 1 & 1 & $24 \mathrm{~h}$ & None stated & $\begin{array}{l}100 \% \text { reduction in } \\
\text { norepinephrine use }\end{array}$ \\
\hline Marek et al. [56] & $\begin{array}{l}\text { Cardiogenic } \\
\text { shock, post } \\
\text { cardiac arrest }\end{array}$ & 1 & 4 & $4 \times 24 h$ & None stated & $\begin{array}{c}36 \% \text { reduction in } \\
\text { norepinephrine on } \\
\text { day } 1,31 \% \\
\text { reduction day } 2, \\
34 \% \text { reduction day } \\
3\end{array}$ \\
\hline Friesecke et al. [13] & $\begin{array}{c}\text { Refractory septic } \\
\text { shock }\end{array}$ & 20 & 3 & $3 \times 24 h$ & $\begin{array}{l}\text { Primary endpoint; } \\
\text { change in } \\
\text { norepinephrine } \\
\text { requirement after } 6 \\
\text { and } 12 \text { h of treatment } \\
\text { with CytoSorb } \\
\text { compared with start }\end{array}$ & $\begin{array}{l}51 \% \text { reduction in } \\
\text { norepinephrine in } \\
\text { first } 24 \mathrm{~h}\end{array}$ \\
\hline Napp et al. [57] & $\begin{array}{l}\text { Acute poison- } \\
\text { ing/intoxication }\end{array}$ & 1 & 2 & $2 \times 24 \mathrm{~h}$ & None stated & $\begin{array}{c}50 \% \text { reduction in } \\
\text { norepinephrine day } \\
1,100 \% \text { reduction } \\
\text { day } 2\end{array}$ \\
\hline Steltzer et al. [58] & Septic Shock & 1 & 6 & $12 \mathrm{~h}$ each & None stated & $\begin{array}{l}36.6 \% \text { reduction in } \\
\text { norepinephrine } \\
\text { requirement on day } \\
1\end{array}$ \\
\hline
\end{tabular}


Table A1. Cont.

\begin{tabular}{|c|c|c|c|c|c|c|}
\hline Reference & Type of Patients & Num of pts & $\begin{array}{c}\text { Avg. Num } \\
\text { of Adsorbers }\end{array}$ & $\begin{array}{l}\text { Time Frame } \\
\text { for Use }\end{array}$ & End Points & Results \\
\hline Eid et al. [59] & $\begin{array}{l}\text { Necrotizing } \\
\text { fasciitis }\end{array}$ & 1 & 2 & $2 \times 24 \mathrm{~h}$ & None stated & $\begin{array}{l}\text { 95\% reduction in } \\
\text { norepinephrine } \\
\text { requirements over } \\
48 \mathrm{~h}\end{array}$ \\
\hline Nemeth et al. [60] & $\begin{array}{l}\text { Cardiac } \\
\text { transplant }\end{array}$ & 24 & 24 & Intra-op use & $\begin{array}{c}\text { Primary outcome: } \\
\text { hemodynamic } \\
\text { stability and } \\
\text { vasopressor demand } \\
\text { during first } 48 \mathrm{~h} \\
\text { post-op; magnitude of } \\
\text { postoperative } \\
\text { inflammatory } \\
\text { response (PCT and } \\
\text { CRP) }\end{array}$ & $\begin{array}{l}57 \% \text { reduction in } \\
\text { norepinephrine } \\
\text { requirements on } \\
\quad \text { day } 1\end{array}$ \\
\hline Nemeth et al. [61] & $\begin{array}{l}\text { Septic shock, } \\
\text { cardiogenic shock }\end{array}$ & 1 & 1 & $1 \times 24 \mathrm{~h}$ & None stated & $\begin{array}{c}100 \% \text { reduction in } \\
\text { norepinephrine in } \\
24 \mathrm{~h}\end{array}$ \\
\hline Dogan et al. [62] & $\begin{array}{l}\text { Cardiogenic } \\
\text { shock }\end{array}$ & 1 & 9 & $\begin{array}{l}9 \times 24 \mathrm{~h} \text { with } \\
23 \text { day pause }\end{array}$ & None stated & $\begin{array}{c}61.54 \% \text { reduction in } \\
\text { norepinephrine on } \\
\text { day } 1,12.5 \% \\
\text { increase day } 2 \\
33.3 \% \text { reduction } \\
\text { day } 3,8.33 \% \\
\text { reduction day } 4\end{array}$ \\
\hline Leonardis et al. [63] & $\begin{array}{l}\text { Pneumococcal } \\
\text { Sepsis } \\
\text { Pt } 1\end{array}$ & 1 & 4 & Over $68 \mathrm{~h}$ & None stated & $\begin{array}{c}\text { Initial increase in } \\
\text { norepinephrine on } \\
\text { day } 1(150 \%), 20 \% \\
\text { decrease day 2, 50\% } \\
\text { decrease day3, } 75 \% \\
\text { decrease day } 4\end{array}$ \\
\hline Leonardis et al. [63] & $\begin{array}{l}\text { Meningococcal } \\
\text { Sepsis } \\
\text { Pt } 3\end{array}$ & 1 & 2 & Over $32 \mathrm{~h}$ & None stated & $\begin{array}{c}60 \% \text { decrease in } \\
\text { norepinephrine on } \\
\text { day } 1 \text { and } 100 \% \\
\text { decrease on day } 2\end{array}$ \\
\hline Leonardis et al. [63] & $\begin{array}{l}\text { Meningococcal } \\
\text { Sepsis } \\
\text { Pt } 4\end{array}$ & 1 & 4 & $4 \times 24 h$ & None stated & $\begin{array}{c}20 \% \text { decrease on } \\
\text { day on of } \\
\text { norepinephrine, } \\
37.5 \% \text { decrease day } \\
2,20 \% \text { decrease day } \\
3,100 \% \text { decrease } \\
\text { day } 4\end{array}$ \\
\hline Leonardis et al. [63] & $\begin{array}{c}\text { Meningococcal } \\
\text { Sepsis } \\
\operatorname{Pt} 4\end{array}$ & 1 & 4 & $4 \times 24 \mathrm{~h}$ & None stated & $\begin{array}{c}20 \% \text { decrease on } \\
\text { day on of } \\
\text { norepinephrine, } \\
37.5 \% \text { decrease day } \\
2,20 \% \text { decrease day } \\
3,100 \% \text { decrease } \\
\text { day } 4\end{array}$ \\
\hline Hawchar et al. [64] & Septic shock & 10 & 1 & $1 \times 24 \mathrm{~h}$ & $\begin{array}{l}\text { Organ dysfunction } \\
\text { and inflammatory } \\
\text { response }\end{array}$ & $\begin{array}{l}37 \% \text { reduction seen } \\
\text { in norepinephrine } \\
\text { on day } 1\end{array}$ \\
\hline Kuhne et al. [65] & $\begin{array}{l}\text { Intra-op cardiac } \\
\text { surgery }\end{array}$ & 10 & 1 & $\begin{array}{l}\text { Intra-op use } \\
\text { only }\end{array}$ & None stated & $\begin{array}{l}37.5 \% \text { reduction in } \\
\text { norepinephrine use }\end{array}$ \\
\hline Kuhne et al. [65] & $\begin{array}{l}\text { Intra- and post-op } \\
\text { cardiac Surgery }\end{array}$ & 10 & 1 & $\begin{array}{c}\text { Intra- and } \\
\text { post-op use for } \\
72 \mathrm{~h}\end{array}$ & None stated & $\begin{array}{l}75 \% \text { reduction in } \\
\text { norepinephrine use }\end{array}$ \\
\hline Poli et al. [66] & Septic shock & 1 & 4 & $\begin{array}{l}1 \times 9 h \\
3 \times 24 h\end{array}$ & None stated & $\begin{array}{c}0 \% \text { reduction } \\
\text { norepinephrine use } \\
\text { day } 1,80 \% \text { day } 2, \\
50 \% \text { on day } 3,100 \% \\
\text { on day } 4\end{array}$ \\
\hline
\end{tabular}


Table A1. Cont.

\begin{tabular}{|c|c|c|c|c|c|c|}
\hline Reference & Type of Patients & Num of pts & $\begin{array}{c}\text { Avg. Num } \\
\text { of Adsorbers }\end{array}$ & $\begin{array}{l}\text { Time Frame } \\
\text { for Use }\end{array}$ & End Points & Results \\
\hline Perez et al. [67] & $\begin{array}{c}\text { Pediatric } \\
\text { cardiogenic shock }\end{array}$ & 1 & 1 & $1 \times 72 \mathrm{~h}$ & None stated & $\begin{array}{c}27 \% \text { reduction } \\
\text { norepinephrine use } \\
\text { day } 1,45 \% \\
\text { reduction day } 2, \\
14 \% \text { reduction day } \\
3,100 \% \text { reduction } \\
\text { day } 4\end{array}$ \\
\hline Frimmel et al. [68] & $\begin{array}{c}\text { Septic shock, ALF, } \\
\text { HLH. Pt } 1\end{array}$ & 1 & 1 & $24 \mathrm{~h}$ & None stated & $\begin{array}{l}58 \% \text { reduction in } \\
\text { norepinephrine }\end{array}$ \\
\hline Frimmel et al. [68] & $\begin{array}{c}\text { Septic shock, } \\
\text { HLH } \\
\text { Pt } 2\end{array}$ & 1 & 2 & $2 \times 24 \mathrm{~h}$ & None stated & $\begin{array}{l}0 \% \text { reduction in } \\
\text { norepinephrine on } \\
\text { day } 1,28.6 \% \\
\text { reduction on day } 2, \\
100 \% \text { reduction } \\
\text { day } 3\end{array}$ \\
\hline De Schryven et al. [69] & $\begin{array}{l}\text { Acute poison- } \\
\text { ing/intoxication }\end{array}$ & 1 & 1 & Not stated & None stated & $\begin{array}{l}92.3 \text { reduction in } \\
\text { norepinephrine } \\
\text { over } 3 \text { days }\end{array}$ \\
\hline Klinkmann et al. [70] & Fungal sepsis & 1 & 1 & $20 \mathrm{~h}$ & None stated & $\begin{array}{l}78 \% \text { reduction in } \\
\text { norepinephrine use } \\
\text { on first day }\end{array}$ \\
\hline Dimski et al. [71] & Septic shock & 11 & 1 & $1 \times 24 \mathrm{~h}$ & $\begin{array}{l}\text { Primary endpoint: } \\
\text { feasibility of } \\
\text { combined } \\
\text { CytoSorb/CVVHD } \\
\text { treatment with RCA }\end{array}$ & $\begin{array}{l}66 \% \text { reduction in } \\
\text { norepinephrine use } \\
\text { on first day }\end{array}$ \\
\hline Traegar at al. [72] & $\begin{array}{l}\text { Cardiogenic } \\
\text { shock post } \\
\text { cardiac surgery }\end{array}$ & 23 & 2 & $\begin{array}{l}\text { Various lengths } \\
\text { of time }\end{array}$ & None stated & $\begin{array}{l}87 \% \text { reduction in } \\
\text { norepinephrine use } \\
\text { on day } 1,80 \% \\
\text { reduction on day } 2\end{array}$ \\
\hline Stahl et al. [73] & $\begin{array}{l}\text { Cytokine release } \\
\text { syndrome }\end{array}$ & 1 & 5 & $\begin{array}{l}\text { Various lengths } \\
\text { of time }\end{array}$ & None stated & $\begin{array}{c}47 \% \text { decrease in } \\
\text { norepinephrine on } \\
\text { day } 1,57 \% \\
\text { reduction on day } 2\end{array}$ \\
\hline Dilken et al. [74] & Myoglobinemia & 1 & 3 & 12-hourly & None stated & $\begin{array}{c}8 \% \text { reduction in } \\
\text { norepinephrine on } \\
\text { day } 1,34 \% \\
\text { reduction on day } 2\end{array}$ \\
\hline Akil et al. [75] & $\begin{array}{l}\text { Septic shock, } \\
\text { ARDS }\end{array}$ & 13 & 2 & $24 \mathrm{~h}$ & 30 day mortality & $\begin{array}{c}92.54 \% \text { reduction in } \\
\text { norepinephrine on } \\
\text { day } 1,89 \% \\
\text { reduction on day 2, } \\
\begin{array}{c}100 \% \text { reduction on } \\
\text { day } 3\end{array}\end{array}$ \\
\hline Wallet et al. [76] & $\begin{array}{l}\text { Cytokine release } \\
\text { syndrome }\end{array}$ & 1 & 2 & $24 \mathrm{~h}$ & None stated & $\begin{array}{c}100 \% \text { reduction in } \\
\text { norepinephrine on } \\
\text { day } 1\end{array}$ \\
\hline Mehta et al. [77] & $\begin{array}{l}\text { Major aortic } \\
\text { surgery }\end{array}$ & 8 & 1 & Intr-op use only & $\begin{array}{l}\text { Changes in } \\
\text { inflammatory } \\
\text { markers }\end{array}$ & $\begin{array}{l}77 \% \text { reduction in } \\
\text { norepinephrine on } \\
\text { day } 1,74 \% \\
\text { reduction on day } 2\end{array}$ \\
\hline Alharthy et al. [78] & $\begin{array}{l}\text { COVID-19, acute } \\
\text { kidney injury }\end{array}$ & 50 & 2 & $2 \times 24 \mathrm{~h}$ & None stated & $\begin{array}{l}100 \% \text { reduction in } \\
\text { norepinephrine } \\
\text { over } 2 \text { days in } \\
\text { survivors }\end{array}$ \\
\hline Rugg et al. [79] & Septic Shock & 42 & 1 & $24 \mathrm{~h}$ & None Stated & $\begin{array}{c}52 \% \text { reduction in } \\
\text { norepinephrine on } \\
\text { day } 1,54 \% \\
\text { reduction on day } 2\end{array}$ \\
\hline
\end{tabular}


Table A1. Cont.

\begin{tabular}{|c|c|c|c|c|c|c|}
\hline Reference & Type of Patients & Num of pts & $\begin{array}{l}\text { Avg. Num } \\
\text { of Adsorbers }\end{array}$ & $\begin{array}{l}\text { Time Frame } \\
\text { for Use }\end{array}$ & End Points & Results \\
\hline Rieder et al. [80] & ARDS and ECMO & 9 & 3 & $3 \times 24 h$ & None Stated & $\begin{array}{c}37.5 \% \text { reduction in } \\
\text { norepinephrine on } \\
\text { day } 1,50 \% \text { day } 2 \\
\text { and } 100 \% \text { by day } 3 .\end{array}$ \\
\hline Boss et al. [81] & $\begin{array}{l}\text { Septic shock after } \\
\text { cardiac surgery }\end{array}$ & 98 & 1 & $24 \mathrm{~h}$ & None Stated & $\begin{array}{c}51.02 \% \text { reduction in } \\
\text { norepinephrine use, } \\
\text { average use at least } \\
15 \mathrm{~h}\end{array}$ \\
\hline
\end{tabular}

\section{References}

1. Singer, M.; Deutschman, C.S.; Seymour, C.W.; Shankar-Hari, M.; Annane, D.; Bauer, M.; Bellomo, R.; Bernard, G.R.; Chiche, J.D.; Coopersmith, C.M.; et al. The Third International Consensus Definitions for Sepsis and Septic Shock (Sepsis-3). JAMA 2016, 315, 801-810. [CrossRef]

2. Gerlach, H. Agents to reduce cytokine storm. F1000Research 2016, 5, 2909. [CrossRef] [PubMed]

3. Marshall, J.C. Inflammation, coagulopathy, and the pathogenesis of multiple organ dysfunction syndrome. Crit. Care Med. 2001, 29, S99-S106. [CrossRef] [PubMed]

4. Gruda, M.C.; Ruggeberg, K.G.; O'Sullivan, P.; Guliashvili, T.; Scheirer, A.R.; Golobish, T.D.; Capponi, V.J.; Chan, P.P. Broad adsorption of sepsis-related PAMP and DAMP molecules, mycotoxins, and cytokines from whole blood using CytoSorb(R) sorbent porous polymer beads. PLoS ONE 2018, 13, e0191676. [CrossRef] [PubMed]

5. Malard, B.; Lambert, C.; Kellum, J.A. In vitro comparison of the adsorption of inflammatory mediators by blood purification devices. Intensive Care Med. Exp. 2018, 6, 12. [CrossRef]

6. Cecconi, M.; De Backer, D.; Antonelli, M.; Beale, R.; Bakker, J.; Hofer, C.; Jaeschke, R.; Mebazaa, A.; Pinsky, M.R.; Teboul, J.L.; et al. Consensus on circulatory shock and hemodynamic monitoring. Task force of the European Society of Intensive Care Medicine. Intensive Care Med. 2014, 40, 1795-1815. [CrossRef]

7. Vincent, J.L.; De Backer, D. Circulatory shock. N. Engl. J. Med. 2013, 369, 1726-1734. [CrossRef]

8. Virág, M.; Leiner, T.; Rottler, M.; Ocskay, K.; Molnar, Z. Individualized Hemodynamic Management in Sepsis. J. Pers. Med. 2021, 11, 157. [CrossRef]

9. Barbee, R.W.; Reynolds, P.S.; Ward, K.R. Assessing shock resuscitation strategies by oxygen debt repayment. Shock 2010, 33, 113-122. [CrossRef] [PubMed]

10. Vincent, J.-L.; Opal, S.M.; Marshall, J.C.; Tracey, K.J. Sepsis definitions: Time for change. Lancet 2013, 381, 774-775. [CrossRef]

11. Osler, W. The Evolution of Modern Medicine: A Series of Lectures Delivered at Yale University; Kessinger Publishing: Whitefish, MT, USA, 1913; reprint 2004.

12. Selye, H.A. A syndrome produced by diverse nocuous agents. Nature 1936, 138, 32. [CrossRef]

13. Friesecke, S.; Stecher, S.S.; Gross, S.; Felix, S.B.; Nierhaus, A. Extracorporeal cytokine elimination as rescue therapy in refractory septic shock: A prospective single-center study. J Artif. Organs 2017, 20, 252-259. [CrossRef]

14. Sakr, Y.; Reinhart, K.; Vincent, J.L.; Sprung, C.L.; Moreno, R.; Ranieri, V.M.; De Backer, D.; Payen, D. Does dopamine administration in shock influence outcome? Results of the Sepsis Occurrence in Acutely Ill Patients (SOAP) Study. Crit. Care Med. 2006, 34, 589-597. [CrossRef] [PubMed]

15. De Backer, D.; Biston, P.; Devriendt, J.; Madl, C.; Chochrad, D.; Aldecoa, C.; Brasseur, A.; Defrance, P.; Gottignies, P.; Vincent, J.L.; et al. Comparison of dopamine and norepinephrine in the treatment of shock. N. Engl. J. Med. 2010, 362, 779-789. [CrossRef]

16. Varpula, M.; Tallgren, M.; Saukkonen, K.; Voipio-Pulkki, L.M.; Pettila, V. Hemodynamic variables related to outcome in septic shock. Intensive Care Med. 2005, 31, 1066-1071. [CrossRef]

17. Dunser, M.W.; Ruokonen, E.; Pettila, V.; Ulmer, H.; Torgersen, C.; Schmittinger, C.A.; Jakob, S.; Takala, J. Association of arterial blood pressure and vasopressor load with septic shock mortality: A post hoc analysis of a multicenter trial. Crit. Care 2009, 13, R181. [CrossRef]

18. Rhodes, A.; Evans, L.E.; Alhazzani, W.; Levy, M.M.; Antonelli, M.; Ferrer, R.; Kumar, A.; Sevransky, J.E.; Sprung, C.L.; Nunnally, M.E.; et al. Surviving Sepsis Campaign: International Guidelines for Management of Sepsis and Septic Shock: 2016. Crit. Care Med. 2017, 45, 486-552. [CrossRef] [PubMed]

19. De Backer, D.; Foulon, P. Minimizing catecholamines and optimizing perfusion. Crit. Care 2019, 23, 149. [CrossRef] [PubMed]

20. Hamzaoui, O.; Shi, R. Early norepinephrine use in septic shock. J. Thorac. Dis. 2020, 12, S72-S77. [CrossRef]

21. Bai, X.; Yu, W.; Ji, W.; Lin, Z.; Tan, S.; Duan, K.; Dong, Y.; Xu, L.; Li, N. Early versus delayed administration of norepinephrine in patients with septic shock. Crit. Care 2014, 18, 532. [CrossRef]

22. Ospina-Tascon, G.A.; Hernandez, G.; Alvarez, I.; Calderon-Tapia, L.E.; Manzano-Nunez, R.; Sanchez-Ortiz, A.I.; Quinones, E.; Ruiz-Yucuma, J.E.; Aldana, J.L.; Teboul, J.L.; et al. Effects of very early start of norepinephrine in patients with septic shock: A propensity score-based analysis. Crit. Care 2020, 24, 52. [CrossRef] 
23. Levy, B.; Fritz, C.; Tahon, E.; Jacquot, A.; Auchet, T.; Kimmoun, A. Vasoplegia treatments: The past, the present, and the future. Crit. Care 2018, 22, 52. [CrossRef]

24. Cheng, L.; Yan, J.; Han, S.; Chen, Q.; Chen, M.; Jiang, H.; Lu, J. Comparative efficacy of vasoactive medications in patients with septic shock: A network meta-analysis of randomized controlled trials. Crit. Care 2019, 23, 168. [CrossRef] [PubMed]

25. Kogelmann, K.; Jarczak, D.; Scheller, M.; Druner, M. Hemoadsorption by CytoSorb in septic patients: A case series. Crit. Care 2017, 21, 74. [CrossRef]

26. Tomescu, D.; Popescu, M.; David, C.; Dima, S. Clinical effects of hemoadsorption with CytoSorb((R)) in patients with severe acute pancreatitis: A case series. Int. J. Artif. Organs. 2019, 42, 190-193. [CrossRef]

27. Mehta, Y.; Mehta, C.; Kumar, A.; George, J.V.; Gupta, A.; Nanda, S.; Kochhar, G.; Raizada, A. Experience with hemoadsorption (CytoSorb) in the management of septic shock patients. World J. Crit. Care Med. 2020, 9, 1-12. [CrossRef]

28. Kousoulas, L.; Wittel, U.; Fichtner-Feigl, S.; Utzolino, S. Hemoadsorption in a Case of Severe Septic Shock and Necrotizing Fasciitis Caused by Nontraumatic Renal Rupture due to Pyelonephritis with Obstructive Uropathy. Case Rep Crit. Care 2018, 2018, 5248901. [CrossRef] [PubMed]

29. Krishan, K.; Dutta, R.; Chand, R.; Malhotra, R. Experience of using an extracorporeal cytokine hemoadsorber (CytoSorb $\left.{ }^{\circledR}\right)$ in systemic inflammatory response syndrome after heart transplantation. Indian J. Transplant. 2020, 14, 166-169. [CrossRef]

30. Rizvi, S.; Danic, M.; Silver, M.; LaBond, V. Cytosorb filter: An adjunct for survival in the COVID-19 patient in cytokine storm? a case report. Heart Lung 2021, 50, 44-50. [CrossRef]

31. Breuer, T.G.K.; Quast, D.R.; Wiciok, S.; Labedi, A.; Ellrichmann, G. Successful Treatment of Severe Digitoxin Intoxication with CytoSorb®Hemoadsorption. Blood Purif. 2020, 50, 137-140. [CrossRef] [PubMed]

32. Schittek, G.A.; Zoidl, P.; Eichinger, M.; Orlob, S.; Simonis, H.; Rief, M.; Metnitz, P.; Fellinger, T.; Soukup, J. Adsorption therapy in critically ill with septic shock and acute kidney injury: A retrospective and prospective cohort study. Ann.Intensive Care 2020, 10, 154. [CrossRef]

33. Popescu, M.; Dima, S.; David, C.; Tudor, A.; Simionescu, M.; Tomescu, D. Standard renal replacement therapy combined with hemoadsorption in the treatment of critically ill septic patients. Ther. Apher. Dial. 2020. [CrossRef]

34. Tomescu, D.; Popescu, M.; David, C.; Sima, R.; Dima, S. Haemoadsorption by CytoSorb(R) in patients with acute liver failure: A case series. Int. J. Artif. Organs. 2020. [CrossRef]

35. Rademacher, J.-G.; Wulf, G.; Koziolek, M.J.; Zeisberg, M.; Wallbach, M. Cytokine adsorption therapy in lymphoma-associated hemophagocytic lymphohistiocytosis and allogeneic stem cell transplantation. J. Artif. Organs. 2021. [CrossRef]

36. Santer, D.; Miazza, J.; Koechlin, L.; Gahl, B.; Rrahmani, B.; Hollinger, A.; Eckstein, F.S.; Siegemund, M.; Reuthebuch, O.T. Hemoadsorption during Cardiopulmonary Bypass in Patients with Endocarditis Undergoing Valve Surgery: A Retrospective Single-Center Study. J. Clin. Med. 2021, 10, 564. [CrossRef] [PubMed]

37. Surendra, M.; Cherukuri, B.; Kumar, S.; Harithra, N.; Kantham, L.; Silpa; Bhavya; Srikanth; Jyothi, Y. A retrospective analysis of efficacy of hemoadsorption (CytoSorb $\left.{ }^{\circledR}\right)$ in refractory septic shock patients as an adjuvant. Int. J. Sci. Res. 2019, 8, 1-3.

38. Milella, L.; Ficarella, M.; Calabrese, G.; Sisto, M.; Grieco, N.; Moliterni, P.; Raimondo, P.; Cito, F.; Bellino, V.; Ranieri, M.; et al. Application of hemoadsorption in neonatal and pediatric hyperinflammatory states: A case series. Am. J. Pediatr. 2019, 5, 34-42. [CrossRef]

39. Saparov, A.; Sazonov, V.; Tobylbaeva, Z.; Isakov, S.; Bekpan, A.; Autalipov, D.; Muratbekova, B.; Manaybekova, Z.; Anikin, V. First successful hemoadsorption using CytoSorb(R) in a septic pediatric patient in Kazakhstan: A case report. Int. J. Artif. Organs. 2019, 42, 315-317. [CrossRef]

40. Akin, M.; Garcheva, V.; Sieweke, J.T.; Flierl, U.; Daum, H.C.; Bauersachs, J.; Schafer, A. Early use of hemoadsorption in patients after out-of hospital cardiac arrest-A matched pair analysis. PLoS ONE 2020, 15, e0241709. [CrossRef]

41. Haidari, Z.; Wendt, D.; Thielmann, M.; Mackowiak, M.; Neuhäuser, M.; Jakob, H.; Ruhparwar, A.; El-Gabry, M. Intraoperative hemoadsorption in patients with native mitral valve infective endocarditis. Ann. Thorac. Surg. 2020, 110, 890-896. [CrossRef]

42. Paul, R.; Sathe, P.; Kumar, S.; Prasad, S.; Aleem, M.; Sakhalvalkar, P. Multicentered prospective investigator initiated study to evaluate the clinical outcomes with extracorporeal cytokine adsorption device (CytoSorb®) in patients with sepsis and septic shock. World J. Crit. Care Med. 2021, 10, 22-34. [CrossRef] [PubMed]

43. Saller, T.; Hagl, C.; Woitsch, S.; Li, Y.; Niedermayer, S.; Born, F.; Luehr, M.; Kammerer, T.; Pichlmaier, M.; Scheiermann, P.; et al. Haemadsorption improves intraoperative haemodynamics and metabolic changes during aortic surgery with hypothermic circulatory arrest. Eur. J. Cardiothorac. Surg. 2019, 56, 731-737. [CrossRef] [PubMed]

44. Rieder, M.; Wengenmayer, T.; Staudacher, D.; Duerschmied, D.; Supady, A. Cytokine adsorption in patients with severe COVID-19 pneumonia requiring extracorporeal membrane oxygenation. Crit. Care 2020, 24, 435. [CrossRef]

45. Mezger, M.; Eitel, I.; Ensminger, S.; Pogorzalek, D.; Huang, Z.; Graf, T. Sequential Use of Hemadsorption Using Cytosorb®and Biosky®Filter-Technology in A COVID-19 Patient Suffering from Severe ARDS. Arch. Clin. Med. Case Rep. 2020, 4, 969-977. [CrossRef]

46. Prakash, A.; Garg, V.; Mittal, D.K.; Upadhyay, A.B. CytoSorb in the management of severe septic shock after coronary artery bypass graft surgery. Heart India 2020, 8, 151-153.

47. Alharthy, A.; Balhamar, A.; Faqihi, F.; Nasim, N.; Noor, A.; Alqahtani, S.A.; Memish, Z.A.; Karakitsos, D. COVID-19 presenting as acute abdomen and sepsis: A rare case-report. New Microbes New Infect. 2020, 38, 100818. [CrossRef] 
48. Taccone, F.S.; Gardette, M.; Creteur, J.; Brasseur, A.; Lorent, S.; Grimaldi, D. Hemoadsorption to treat severe iatrogenic intoxication with Patent Blue: A case report. J. Med. Case Rep. 2021, 15, 63. [CrossRef]

49. Zickler, D.; Nee, J.; Arnold, T.; Schroder, T.; Slowinski, T.; Eckardt, K.U.; Korner, R.; Kruse, J.M. Use of Hemoadsorption in Patients With Severe Intoxication Requiring Extracorporeal Cardiopulmonary Support-A Case Series. ASAIO J. 2021. [CrossRef]

50. Mitzner, S.R.; Gloger, M.; Henschel, J.; Koball, S. Improvement of hemodynamic and inflammatory parameters by combined hemoadsorption and hemodiafiltration in septic shock: A case report. Blood Purif. 2013, 35, 314-315. [CrossRef]

51. Hetz, H.; Berger, R.; Recknagel, P.; Steltzer, H. Septic shock secondary to beta-hemolytic streptococcus-induced necrotizing fasciitis treated with a novel cytokine adsorption therapy. Int. J. Artif. Organs. 2014, 37, 422-426. [CrossRef]

52. Frimmel, S.; Schipper, J.; Henschel, J.; Yu, T.T.; Mitzner, S.R.; Koball, S. First description of single-pass albumin dialysis combined with cytokine adsorption in fulminant liver failure and hemophagocytic syndrome resulting from generalized herpes simplex virus 1 infection. Liver Transpl. 2014, 20, 1523-1524. [CrossRef]

53. Hinz, B.; Jauch, O.; Noky, T.; Friesecke, S.; Abel, P.; Kaiser, R. CytoSorb, a novel therapeutic approach for patients with septic shock: A case report. Int. J. Artif. Organs. 2015, 38, 461-464. [CrossRef]

54. Traeger, K.; Schutz, C.; Fischer, G.; Schroder, J.; Skrabal, C.; Liebold, A.; Reinelt, H. Cytokine Reduction in the Setting of an ARDS-Associated Inflammatory Response with Multiple Organ Failure. Case Rep. Crit. Care 2016, 2016, 9852073. [CrossRef] [PubMed]

55. Van der Linde, G.W.; Grootendorst, A. First case of toxic shock treated with haemoadsorption by CytoSorb®in the Netherlands Neth.J. Crit. Care 2016, 24, 27-29.

56. Marek, S.; Gamper, G.; Reining, G.; Bergmann, P.; Mayr, H.; Kliegel, A. ECMO and cytokine removal for bridging to surgery in a patient with ischemic ventricular septal defect-A case report. Int. J. Artif. Organs. 2017, 40, 526-529. [CrossRef] [PubMed]

57. Napp, L.C.; Vogel-Claussen, J.; Schafer, A.; Haverich, A.; Bauersachs, J.; Kuhn, C.; Tongers, J. First-in-Man Fully Percutaneous Complete Bypass of Heart and Lung. JACC Cardiovasc. Interv. 2017, 10, e231-e233. [CrossRef] [PubMed]

58. Steltzer, H.; Grieb, A.; Mostafa, K.; Berger, R. Use of CytoSorb in Traumatic Amputation of the Forearm and Severe Septic Shock. Case Rep. Crit. Care 2017, 2017, 8747616. [CrossRef] [PubMed]

59. Eid, M.; Fouquet, O.; Darreau, C.; Pierrot, M.; Kouatchet, A.; Mercat, A.; Baufreton, C. Successfully treated necrotizing fasciitis using extracorporeal life support combined with hemoadsorption device and continuous renal replacement therapy. Int. J. Artif. Organs. 2018, 41, 178-182. [CrossRef]

60. Nemeth, E.; Kovacs, E.; Racz, K.; Soltesz, A.; Szigeti, S.; Kiss, N.; Csikos, G.; Koritsanszky, K.B.; Berzsenyi, V.; Trembickij, G.; et al. Impact of intraoperative cytokine adsorption on outcome of patients undergoing orthotopic heart transplantation-An observational study. Clin. Transpl. 2018, 32, e13211. [CrossRef]

61. Nemeth, E.; Szigeti, S.; Varga, T.; Daroczi, L.; Barati, Z.; Merkely, B.; Gal, J. Continuous cytokine haemoadsorption incorporated into a venoarterial ECMO circuit for the management of postcardiotomy cardiogenic and septic shock-A case report. Perfusion 2018, 33, 595-596. [CrossRef]

62. Dogan, G.; Hanke, J.; Puntigam, J.; Haverich, A.; Schmitto, J.D. Hemoadsorption in cardiac shock with biventricular failure and giant-cell myocarditis: A case report. Int. J. Artif. Organs. 2018, 41, 474-479. [CrossRef]

63. Leonardis, F.; De Angelis, V.; Frisardi, F.; Pietrafitta, C.; Riva, I.; Martino Valetti, T.; Broletti, V.; Marchesi, G.; Menato, L.; Nani, R.; et al. Effect of hemoadsorption for cytokine removal in pneumococcal and meningococcal sepsis. Case Rep. Crit. Care 2018, 2018, 1205613. [CrossRef] [PubMed]

64. Hawchar, F.; László, I.; Öveges, N.; Trásy, D.; Ondrik, Z.; Molnar, Z. Extracorporeal cytokine adsorption in septic shock: A proof of concept randomized, controlled pilot study. J. Crit. Care 2019, 49, 172-178. [CrossRef] [PubMed]

65. Kühne, L.U.; Binczyk, R.; Riess, F.C. Comparison of intraoperative versus intraoperative plus postoperative hemoadsorption therapy in cardiac surgery patients with endocarditis. Int. J. Artif. Organs 2019, 42, 194-200. [CrossRef]

66. Poli, E.C.; Simoni, C.; Andre, P.; Buclin, T.; Longchamp, D.; Perez, M.H.; Ferry, T.; Schneider, A.G. Clindamycin clearance during Cytosorb $((\mathrm{R}))$ hemoadsorption: A case report and pharmacokinetic study. Int. J. Artif. Organs 2019, 42, 258-262. [CrossRef]

67. Perez, M.H.; Maitre, G.; Longchamp, D.; Amiet, V.; Natterer, J.; Ferry, T.; Schneider, A.; Plaza Wuthrich, S.; Di Bernardo, S. CytoSorb $((\mathrm{R}))$ hemoadsorption and mechanical circulatory support in a newborn with refractory shock after congenital heart surgery. Int. J. Artif. Organs 2019, 42, 521-524. [CrossRef]

68. Frimmel, S.; Hinz, M.; Schipper, J.; Bogdanow, S.; Mitzner, S.; Koball, S. Cytokine adsorption is a promising tool in the therapy of hemophagocytic lymphohistiocytosis. Int. J. Artif. Organs 2019, 42, 658-664. [CrossRef] [PubMed]

69. De Schryver, N.; Hantson, P.; Haufroid, V.; Dechamps, M. Cardiogenic Shock in a Hemodialyzed Patient on Flecainide: Treatment with Intravenous Fat Emulsion, Extracorporeal Cardiac Life Support, and CytoSorb(R) Hemoadsorption. Case Re.p Cardiol 2019, 2019, 1905871. [CrossRef]

70. Klinkmann, G.; Stope, M.B.; Meyer, A. Cytokine adsorption as a promising option for septic shock and multiple organ failure due to Candida infection and decompensated type 1 diabetes mellitus. Artif. Organs 2020, 44, 522-525. [CrossRef]

71. Dimski, T.; Brandenburger, T.; Slowinski, T.; Kindgen-Milles, D. Feasibility and safety of combined cytokine adsorption and continuous veno-venous hemodialysis with regional citrate anticoagulation in patients with septic shock. Int. J. Artif. Organs 2020, 43, 10-16. [CrossRef] [PubMed] 
72. Trager, K.; Skrabal, C.; Fischer, G.; Schroeder, J.; Marenski, L.; Liebold, A.; Reinelt, H.; Datzmann, T. Hemoadsorption treatment with CytoSorb $((\mathrm{R}))$ in patients with extracorporeal life support therapy: A case series. Int. J. Artif. Organs 2020, 43, 422-429. [CrossRef]

73. Stahl, K.; Schmidt, B.M.W.; Hoeper, M.M.; Skripuletz, T.; Mohn, N.; Beutel, G.; Eder, M.; Welte, T.; Ganser, A.; Falk, C.S.; et al. Extracorporeal cytokine removal in severe CAR-T cell associated cytokine release syndrome. J. Crit. Care 2020, 57, 124-129. [CrossRef] [PubMed]

74. Dilken, O.; Ince, C.; van der Hoven, B.; Thijsse, S.; Ormskerk, P.; de Geus, H.R.H. Successful Reduction of Creatine Kinase and Myoglobin Levels in Severe Rhabdomyolysis Using Extracorporeal Blood Purification (CytoSorb(R)). Blood Purif. 2020, 49, 743-747. [CrossRef]

75. Akil, A.; Ziegeler, S.; Reichelt, J.; Rehers, S.; Abdalla, O.; Semik, M.; Fischer, S. Combined Use of CytoSorb and ECMO in Patients with Severe Pneumogenic Sepsis. Thorac. Cardiovasc. Surg. 2021, 69, 246-251.

76. Wallet, F.; Bachy, E.; Vassal, O.; Friggeri, A.; Bohe, J.; Garnier, L.; Salles, G.; Allaouchiche, B. Extracorporeal cytokine adsorption for treating severe refractory cytokine release syndrome (CRS). Bone Marrow Transpl. 2020, 55, 2052-2055. [CrossRef]

77. Mehta, Y.; Singh, A.; Singh, A.; Gupta, A.; Bhan, A. Modulating the Inflammatory Response With Hemadsorption (CytoSorb) in Patients Undergoing Major Aortic Surgery. J. Cardiothorac. Vasc. Anesth. 2021, 35, 673-675. [CrossRef]

78. Alharthy, A.; Faqihi, F.; Memish, Z.A.; Balhamar, A.; Nasim, N.; Shahzad, A.; Tamim, H.; Alqahtani, S.A.; Brindley, P.G.; Karakitsos, D. Continuous renal replacement therapy with the addition of CytoSorb®cartridge in critically ill patients with COVID-19 plus acute kidney injury: A case-series. Artif. Organs 2021, 45, E101-E112. [CrossRef] [PubMed]

79. Rugg, C.; Klose, R.; Hornung, R.; Innerhofer, N.; Bachler, M.; Schmid, S.; Fries, D.; Ströhle, M. Hemoadsorption with CytoSorb in Septic Shock Reduces Catecholamine Requirements and In-Hospital Mortality: A Single-Center Retrospective 'Genetic' Matched Analysis. Biomedicines 2020, 8, 539. [CrossRef] [PubMed]

80. Rieder, M.; Duerschmied, D.; Zahn, T.; Lang, C.; Benk, C.; Lother, A.; Biever, P.; Bode, C.; Wengenmayer, T.; Staudacher, D.; et al. Cytokine Adsorption in Severe Acute Respiratory Failure Requiring Veno-Venous Extracorporeal Membrane Oxygenation. ASAIO J. 2021, 67, 332-338. [CrossRef]

81. Boss, K.; Jahn, M.; Wendt, D.; Haidari, Z.; Demircioglu, E.; Thielmann, M.; Ruhparwar, A.; Kribben, A.; Tyczynski, B. Extracorporeal cytokine adsorption: Significant reduction of catecholamine requirement in patients with AKI and septic shock after cardiac surgery. PLoS ONE 2021, 16, e0246299. [CrossRef]

82. StataCorp. Stata Statistical Software: Release 16; StataCorp LLC: College Station, TX, USA, 2019.

83. Friesenecker, B.E.; Tsai, A.G.; Martini, J.; Ulmer, H.; Wenzel, V.; Hasibeder, W.R.; Intaglietta, M.; Dunser, M.W. Arteriolar vasoconstrictive response: Comparing the effects of arginine vasopressin and norepinephrine. Crit. Care 2006, 10, R75. [CrossRef] [PubMed]

84. Belletti, A.; Castro, M.L.; Silvetti, S.; Greco, T.; Biondi-Zoccai, G.; Pasin, L.; Zangrillo, A.; Landoni, G. The Effect of inotropes and vasopressors on mortality: A meta-analysis of randomized clinical trials. Br. J. Anaesth. 2015, 115, 656-675. [CrossRef]

85. Colling, K.P.; Banton, K.L.; Beilman, G.J. Vasopressors in Sepsis. Surg. Infect. (Larchmt) 2018, 19, 202-207. [CrossRef]

86. Oberbeck, R. Catecholamines: Physiological immunomodulators during health and illness. Curr. Med. Chem. 2006, 13, 1979-1989. [CrossRef]

87. Jenkins, C.R.; Gomersall, C.D.; Leung, P.; Joynt, G.M. Outcome of patients receiving high dose vasopressor therapy: A retrospective cohort study. Anaesth Intensive Care 2009, 37, 286-289. [CrossRef] [PubMed]

88. Auchet, T.; Regnier, M.A.; Girerd, N.; Levy, B. Outcome of patients with septic shock and high-dose vasopressor therapy. Ann. Intensive Care 2017, 7, 43. [CrossRef] [PubMed]

89. Dunser, M.W.; Hasibeder, W.R. Sympathetic overstimulation during critical illness: Adverse effects of adrenergic stress. J. Intensive Care Med. 2009, 24, 293-316. [CrossRef]

90. Labib, A. Sepsis Care Pathway 2019. Qatar Med. J. 2019, 2019, 4. [CrossRef]

91. Bangash, M.N.; Kong, M.L.; Pearse, R.M. Use of inotropes and vasopressor agents in critically ill patients. Br. J. Pharmacol. 2012, 165, 2015-2033. [CrossRef]

92. Lam, S.M.; Lau, A.C.; Lam, R.P.; Yan, W.W. Clinical management of sepsis. Hong Kong Med. J. 2017, 23, 296-305. [CrossRef] [PubMed]

93. Krenn, C.G.; Steltzer, H. Hemoadsorption for blood purification-incomparability of clinically available procedures. Med. Klin Intensivmed. Notfmed. 2021, 116, 449-453. [CrossRef] [PubMed]

94. Ospina-Tascon, G.A.; Buchele, G.L.; Vincent, J.L. Multicenter, randomized, controlled trials evaluating mortality in intensive care: Doomed to fail? Crit. Care Med. 2008, 36, 1311-1322. [CrossRef]

95. Girbes, A.R.J.; de Grooth, H.-J. Time to stop randomized and large pragmatic trials for intensive care medicine syndromes: The case of sepsis and acute respiratory distress syndrome. J. Thorac. Dis. 2020, 12, S101-S109. [CrossRef] [PubMed]

96. Laterre, P.F.; Berry, S.M.; Blemings, A.; Carlsen, J.E.; Francois, B.; Graves, T.; Jacobsen, K.; Lewis, R.J.; Opal, S.M.; Perner, A.; et al. Effect of Selepressin vs. Placebo on Ventilator- and Vasopressor-Free Days in Patients With Septic Shock: The SEPSIS-ACT Randomized Clinical Trial. JAMA 2019, 322, 1476-1485. [CrossRef] [PubMed]

97. Angus, D.C.; Berry, S.; Lewis, R.J.; Al-Beidh, F.; Arabi, Y.; van Bentum-Puijk, W.; Bhimani, Z.; Bonten, M.; Broglio, K.; Brunkhorst, F.; et al. The Randomized Embedded Multifactorial Adaptive Platform for Community-acquired Pneumonia (REMAP-CAP) Study: Rationale and Design. Ann. Am. Thorac. Soc. 2020, 17, 879-891. [CrossRef] 